\title{
SENSORY PROFILE OF ARABICA COFFEE ACCESSES OF THE GERMPLASM COLLECTION OF MINAS GERAIS - BRAZIL
}

\author{
Larissa de Oliveira Fassio ${ }^{1}$, Rosemary Gualberto Fonseca Alvarenga Pereira ${ }^{2}$, \\ Marcelo Ribeiro Malta ${ }^{3}$, Gilberto Rodrigues Liska ${ }^{4}$, Maísa Mancini Matioli Sousa ${ }^{5}$, \\ Gladyston Rodrigues Carvalho ${ }^{6}$, Antônio Alves Pereira ${ }^{7}$
}

(Received: July 08, 2019; accepted: August 28, 2019)

\begin{abstract}
This study was developed to determine the beverage quality and the sensory profile of Coffea arabica accesses of the Germplasm Collection of Minas Gerais State in two consecutive harvests. Mature coffee fruits from 49 accesses were selectively harvested in the 2015 and 2016 harvests, and after processing and drying they were sensorially evaluated by a team of trained judges in accordance to the protocols of the Specialty Coffee Association. The data were analyzed by Principal Component Analysis, Cluster Hierarchical Analysis, and Content Analysis. The year of harvest influences the scores of the sensory attributes of the beverage of some coffee accesses. The access 27 (Pacamara) stood out with the highest sensory score seen in the first year of harvest. The accesses 36 (Timor Hybrid UFV376-52) and 43 (BE5 WushWush) stood out for the final sensory score in the two years of evaluation. All accesses belonging to the Timor Hybrid Germplasm stood out in the beverage quality in the second year of harvest. A total of 139 sensory attribute descriptors were identified, and the content analysis showed different levels for the frequency of terms in each access group formed as a function of quality. The Germplasm Collection of Minas Gerais has a wide variability for the production of superior quality coffees, and the year of harvest influences to a greater or lesser degree the potential of quality of the accesses.
\end{abstract}

Index terms: Genotypes, content analysis, natural processing, beverage quality.

\section{INTRODUCTION}

The consumption of specialty coffees has increased in recent years, mainly due to changes in the behavior of consumers who seek not only its stimulating effect but also pleasure and satisfaction when tasting the beverage. The concept of specialty coffee is broad and depends on the segment to which it applies, therefore, to make an impartial approach it is considered appropriate to use the concept of specialty, something very good, of superior quality and differentiated (Giomo and Borém, 2011). The differentiated quality is related to the characteristics of the beverage, such as taste, aroma, acidity, sweetness and body (Lingle, 2011) formed during roasting by the precursor compounds present in the raw coffee bean, and are mainly influenced by genetic, edafoclimatic and post-harvest factors (Kathurima et al., 2009; Kitzberger et al., 2016; Ribeiro et al., 2016).

The genetic component has an important influence on the definition of taste and aroma of coffee. The species Coffea arabica is the one that has the greatest potential to produce superior quality coffees within the genus Coffea (Teressa et al., 2010; Tessema et al., 2011). C. arabica is native to Ethiopia and has been propagated and disseminated worldwide from a small number of plants, which has led to a narrow genetic basis within this specie (Scholz et al., 2016). Seeking to increase genetic variability, several introductions have been carried out since 1928 and transferred to germplasm collections around the world, maintained to the present day and used for the production of new and more productive cultivars, adapted to regions and resistant to diseases (Scholz et al., 2016; Tessema et al., 2011).

The Coffea accesses of the Germplasm Collection of Minas Gerais State (GC) is composed of approximately 1500 accesses, among them several mutants that represent spontaneous and subspontaneous wild forms of $C$. arabica. Some of these mutations of genetic nature were useful for the development of new cultivars (Lara et al., 2014) some with high potential for beverage quality (Pereira et al., 2010; Fassio et al., 2016; Carvalho et al., 2016). Little is known about the beverage quality of the accesses of the GC of Minas Gerais. In this sense, Sobreira et al. (2015a) and Sobreira et al. (2016) evaluated some accesses of this collection regarding the sensory quality and observed wide genetic variation for the sensory attributes of the beverage. Thus, it is necessary

\footnotetext{
${ }^{1}$ Fundação de Desenvolvimento do Cerrado Mineiro - Rua Rio Branco, 231 - 38.740-000 - Patrocínio - MG - larissafassio@yahoo.com.br ${ }^{2,5}$ Universidade Federal de Lavras/UFLA - Departamento de Ciência dos Alimentos/DCA - Cx. P. 3037 - 37.200-000 - Lavras - MG rosegfap@dca.ufla.br, isamancini_2@hotmail.com

${ }^{3,6,7}$ Empresa de Pesquisa Agropecuária de Minas Gerais/EPAMIG - Avenida José Cândido da Silveira, 1647 - Bairro União 31.170-495 - Belo Horizonte - MG - marcelomalta@epamig.ufla.br, grodriguescarvalho@gmail.com, tonico.epamig@gmail.com ${ }^{4}$ Universidade Federal do Pampa/UNIPAMPA - Rua Luiz Joaquim de Sá Britto, s/n - Bairro Promorar - 97.650-000 - Itaqui - RS gilbertoliska@hotmail.com
} 
to better understand the quality potential of the germplasm implemented in Minas Gerais, to support coffee improvement programs aimed at obtaining new cultivars for the production of specialty coffees.

The climatic conditions during the phenological cycle of coffee trees of Arabica species directly influence the formation of chemical compounds in coffee beans that are precursors to the sensory attributes of the beverage (Pezzopane et al., 2012). In the literature there are no studies comparing the influence of climatic conditions and biennial production on sensory scores of genotypes, however, Kitzberger et al. (2016) evaluated the variation in the composition of lipids, proteins and diterpenes in Arabica coffee cultivars with $C$. canephora introgression as a function of three consecutive harvests, and observed that some cultivars present greater variability in chemical composition as a function of the year of harvest, while others are more stable to this effect, however, these studies did not show results regarding beverage quality.

Due to the importance of the genetic component and climatic conditions in the definition of coffee cultivars, the objective in this study is to evaluate the quality potential of Coffea arabica accesses of the GC at two consecutive harvests as well as to characterize the sensorial profile of these accesses.

\section{MATERIAL AND METHODS}

\section{Description of the study site}

The Germplasm Collection of Minas Gerais (GC) is established at Patrocínio Experimental Farm of Minas Gerais State Agricultural Research Agency (Empresa de Pesquisa Agropecuária do Estado de Minas Gerais - EPAMIG) which is located at $18^{\circ} 59^{\prime} 26^{\prime \prime} \mathrm{S}$ and $48^{\circ} 58^{\prime} 95^{\prime \prime} \mathrm{W}$, at $975 \mathrm{~m}$ altitude, in the Alto Paranaíba region. The soil is of the type dystrophic red-yellow latosol and the topography is flat, with a slight inclination. The climate condition is characterized as Temperate Subtropical Mesothermal, with summer rains, dry winter and hot summer (Wca), according to Koppen classification.

\section{Evaluated Genotypes}

We evaluated 49 accesses (Table 1) of $C$. arabica in two harvests (2015 and 2016). The design was completely randomized in blocks with two replicates and ten plants per plot.

\section{Sample Collection, Processing, and Preparation}

The fruits were harvested selectively when most of them were at their ideal ripening point, i.e., cherry. Eight liters of cherry fruits were selected, washed and dried, in the form of natural processing, in sieves of $1 \mathrm{~m}^{2}$ beamed bottom, under a paved terrace, revolving the fruits 20 times a day until they reached a water content of $11 \%$ (w.b.). After reaching the ideal water content, the samples were packed in Kraft ${ }^{\circledR}$ paper packaging and coated with a polyethylene bag. Then, they were stored in a cold room with a controlled temperature at $17^{\circ} \mathrm{C}$ for a period of 30 days to then be processed and submitted to sensory analysis.

\section{Sensory Analysis}

We performed the roasting and sensory analysis of the samples based on the protocols described by the Specialty Coffee Association SCA (Lingle, 2011). 100g of beans (sieve 16 and above and flawless) of each sample were roasted until they reached the color standard \#65 for whole beans of the Agtron/SCA Color Classification System, respecting the time range of 8 to 12 minutes. For sensory analysis, a panel of three trained judges (Q-grader) evaluated five cups of each sample in relation to ten attributes, fragrance/ aroma, uniformity, absence of flaws, sweetness, flavor, acidity, body, balance, finishing and overall impression, which were graded on a 10-point scale with intervals of 0.25 points. The final sensorial score was generated from the sum of the evaluated attributes, being considered special those coffees with a score equal to or higher than 80 points. The nuances perceived by the judges were also described, allowing greater characterization of the studied accesses.

\section{Data analysis}

We evaluated the beverage quality of 49 accesses of Arabica coffee from the GC in 2 consecutive harvests (2015 and 2016). The results of the sensory attributes and the final score were submitted to multivariate analysis for a better understanding of the effect of the variables studied. To this end, the Principal Components Analysis (PCA) was used to discriminate the accesses from the interaction with the year of harvest, resulting in the grouping of points according to sensory attributes and the final score. In order to visualize the structure and similarity between the accesses, the Hierarchical Grouping Analysis (HCA) was used as a complement to the PCA. For these analyses, we used the statistical software R (R Development Core Team, 2017). 
TABLE 1 - Coding and identification of 49 accesses of C. arabica from the GC.

\begin{tabular}{|c|c|c|c|c|c|}
\hline $\begin{array}{l}\text { Access } \\
\text { Number }\end{array}$ & $\begin{array}{l}\text { Access } \\
\text { Code }\end{array}$ & $\begin{array}{c}\text { Access } \\
\text { Identification }\end{array}$ & $\begin{array}{l}\text { Access } \\
\text { Number }\end{array}$ & $\begin{array}{l}\text { Access } \\
\text { Code }\end{array}$ & $\begin{array}{c}\text { Access } \\
\text { Identification }\end{array}$ \\
\hline 1 & MG0006 & Bourbon Amarelo & 26 & MG0223 & Pacamara \\
\hline 2 & MG0009 & Bourbon Amarelo & 27 & MG0224 & Pacamara \\
\hline 3 & MG0011 & Bourbon Vermelho & 28 & MG0228 & Laurina \\
\hline 4 & MG0016 & Bourbon Vermelho & 29 & MG0230 & Catuaí Erecta \\
\hline 5 & MG0020 & Bourbon Amarelo T7 & 30 & MG0231 & Erecta \\
\hline 6 & MG0036 & Bourbon Amarelo T8 & 31 & MG0233 & Obatã Amarelo \\
\hline 7 & MG0041 & Bourbon Amarelo T13 & 32 & MG0235 & Trifolia \\
\hline 8 & MG0043 & Bourbon Amarelo T15 & 33 & MG0245 & Obatã Tardio \\
\hline 9 & MG0064 & Bourbon Vermelho & 34 & MG0250 & Catucaí Amarelo SL 6 \\
\hline 10 & MG0130 & Sumatrão Ponta Roxa & 35 & MG0258 & Catuaí Vermelho P1 06 \\
\hline 11 & MG0131 & Sumatra & 36 & MG0277 & Híbrido Timor UFV 376-52 \\
\hline 12 & MG0133 & Sumatrão Ponta Roxa & 37 & MG0278 & Híbrido Timor UFV 376-37 \\
\hline 13 & MG0143 & Planta Roxa & 38 & MG0289 & Híbrido Timor UFV 376-01 \\
\hline 14 & MG0152 & Icatu Precoce IAC 3282 & 39 & MG0303 & Híbrido Timor UFV 427-09 \\
\hline 15 & MG0158 & Maragogipe & 40 & MG0448 & Mundo Novo x S 795 UFV 335-15 \\
\hline 16 & MG0175 & Caturra X H.T. IAC 2012 & 41 & MG0545 & Bourbon N39 x H.T. UFV 455-01 \\
\hline 17 & MG0189 & Caturra Alaranjado & 42 & MG0558 & Bourbon N197 x H.T.UFV 403-19 \\
\hline 18 & MG0191 & Caturra Amarelo & 43 & MG0625 & BE 5 Wush-Wush UFV 406-06 \\
\hline 19 & MG0193 & Caturra Amarelo & 44 & MG0865 & Mundo Novo x CIFC H 288/4 UFV 323-59 \\
\hline 20 & MG0194 & Caturra Amarelo Colombiano & 45 & MG1008 & Geisha x S 288/23 UFV 328-69 \\
\hline 21 & MG0216 & Caturra Vermelho UFV 534 C83 & 46 & MG1048 & Sarchimor UFV 350-01 \\
\hline 22 & MG0217 & Caturra Vermelho UFV 534 C 80 & 47 & MG1206 & Bourbon Vermelho \\
\hline 23 & MG0218 & Caturra Amarelo & 48 & MG1218 & Sumatra Fruto Amarelo \\
\hline 24 & MG0219 & Caturra Amarelo & 49 & MG1256 & Mundo Novo II CP 388-17-16 \\
\hline 25 & MG0221 & Caturra Amarelo Nanição & & & \\
\hline
\end{tabular}

Some common criteria are used to define the sensory characteristics of coffee and are mainly divided into two groups: general characteristics and attributes. General characteristics include terms such as fragrance and aroma, acidity, body, taste, aftertaste, and balance, while attributes are descriptors that may not occur in all coffee cups, but when they are present can add complexity and uniqueness to coffee (Thurston et al., 2013). In the sensory analysis of specialty coffees proposed by the Specialty Coffee Association, cupping procedures focus primarily on coffee scoring based on general characteristics, but specific attributes are also identified (Lingle, 2011). However, due to the complexity and variety of terms used by tasters to identify attributes, these descriptions are rarely methodically evaluated (Scholz et al, 2013). In this sense, to evaluate the attributes of the coffee accesses of the GC and trace the sensory profile, we used the Content Analysis Method. Content analysis is a qualitative method that uses thematic analysis strategies and discourse analysis, the first strategy consists of grouping the identified material based on the frequency of words, while the second interprets the meaning of arguments (Bardin, 1977).

\section{RESULTS AND DISCUSSION}

\section{Multivariate data analysis}

The PCA was used as a first approach to multivariate analysis to obtain an overview of the data. The PCA is a supervised method to find the maximum variation within the data set $(\mathrm{X})$ without referring to any class label (Y). The PCA generated scorecard displays key components (PC) responsible for the maximum variation within the data and highlights clusters; while the 
biplot emphasizes the influence of variables on PCs. Variables with high absolute load values in each PC have a strong contribution to that PC. The projection of the accesses for the two years of evaluation can be seen in Figure 1 (a) and the biplot of the sensorial variables in Figure 1 (b). The attributes sweetness, flawlessness, and uniformity were not statistically evaluated because these variables did not present differences in the scores for all the accesses we evaluated. The first two components explained $79.92 \%$ of the response variability (70.92\% for PC1 and 9.0\% for PC2). According to PC1, all sensory variables had a strong influence on the separation of the access groups according to the year of harvest. On the other hand, the variables body, flavor, and fragrance were determinants for the formation of PC2 (Table 2 ). There was the formation of 3 access groups in the two years of harvest according to the sum of the sensory attributes scores. Group I with final scores between 84.0 and 86.3 points according to the SCA protocol for specialty coffees, and therefore the group of the best accesses, Group II with final scores between 82.5 and 83.9 points, defined as intermediate and Group III with final scores between 80.3 and 82.4 points (Figure 1a). Therefore, all accesses are considered specialty coffees, since they have a score above 80 points (Lingle, 2011).

There is variability in the quality of the accesses of coffee in relation to the year of harvest, as can be observed, for example, for the accesses 48 (Sumatra Fruto Amarelo) and 4 (Bourbon Vermelho). The access 48 in the first year of evaluation belongs to the group with the lowest sensory quality (Group III) with 81.6 points, however, in the second year of evaluation, it was in the group of the best coffees (Group I) with 84.3 points. A contrary behavior can be observed in the access 4 that in the first year was classified in Group I, with 85.2 points and in the second year of evaluation this access was classified in Group III with 80.8 points. Thus, it is possible to infer that the year of harvest influenced the maximum expression of the quality of these accesses.

According to PC1 (Figure 2a) the access 27 (Pacamara) in the first year of harvest, and the accesses 36 (Híbrido de Timor UFV 376-52) and 38 (Híbrido de Timor UFV 376-01) in the second year of harvest stood out with the best results in all sensory attributes. On the other hand, the accesses 32 (Trifolia), 25 (Caturra Amarelo Nanição) and 24 (Caturra Amarelo) in the first year of harvest were the accesses with the lowest grades in all sensory attributes evaluated; according to PC2 (Figure 2b), the accesses 7 (Bourbon Amarelo
T13), 11 (Sumatra) and 19 (Caturra Amarelo), all in the second year of harvest, presented the highest scores for the sensory attributes body and the lowest scores for fragrance and flavor. On the other hand, the accesses 1 (Bourbon Amarelo), 29 (Catuaí Erecta) and 47 (Bourbon Vermelho), all from harvest year 1, presented higher scores for flavor and fragrance, and lower scores for body.

The Caturra group comes $100 \%$ from the Bourbon cultivar and the Catuaí group comes from the crossing between Caturra and Mundo Novo. The Mundo Novo cultivar is the result of a natural cross between Sumatra and Bourbon Vermelho (Carvalho, 2008). Therefore, the genetic basis of these accesses is basically Bourbon, which resulted in greater correlation with the scores of flavor and fragrance. The other accesses we evaluated showed little variation between the scores of these attributes but stood out regarding the scores of the attributes acidity, overall impression of the judges and balance, and these were determinants to compose the final scores.

Hierarchical Cluster Analysis (HCA) was also used in order to visualize the structure and similarity between the samples as a complement to the PCA. The HCA is a multivariate analysis that classifies and groups objects based on the dissimilarity matrix. The application of HCA to the evaluated accesses led to the identification of three groups of accesses, according to the sensory scores (Figure 3). Group 1, with sensory scores between 84.0 and 86.3 points, allocated 30 accesses in the two years of harvest (2015 and 2016); Group 2 with scores between 82.5 and 83.9 allocated 50 accesses, being, therefore, the group where most accesses were allocated and, finally, Group 3 with scores between 80.3 and 82.4 , is, therefore, the group with the fewest number of grouped accesses.

According to the results observed in Figure 3 , the accesses 45 (Geisha x S 288/23 UFV 32869) and 20 (Caturra Amarelo Colombiano), regardless of the year of harvest, were allocated to group 3, presenting the lowest sensory scores. This behavior indicates that these accesses do not suffer many variations as a function of the year of harvest regarding the quality of beverage and even being considered special by the SCA protocol, the maximum quality potential is lower when compared to the other accesses we evaluated. In previous studies, Sobreira et al. (2016) also found low sensory potential for the access 20 , which composed the cluster of accesses with final scores from 79 to 80 points. 
(a)
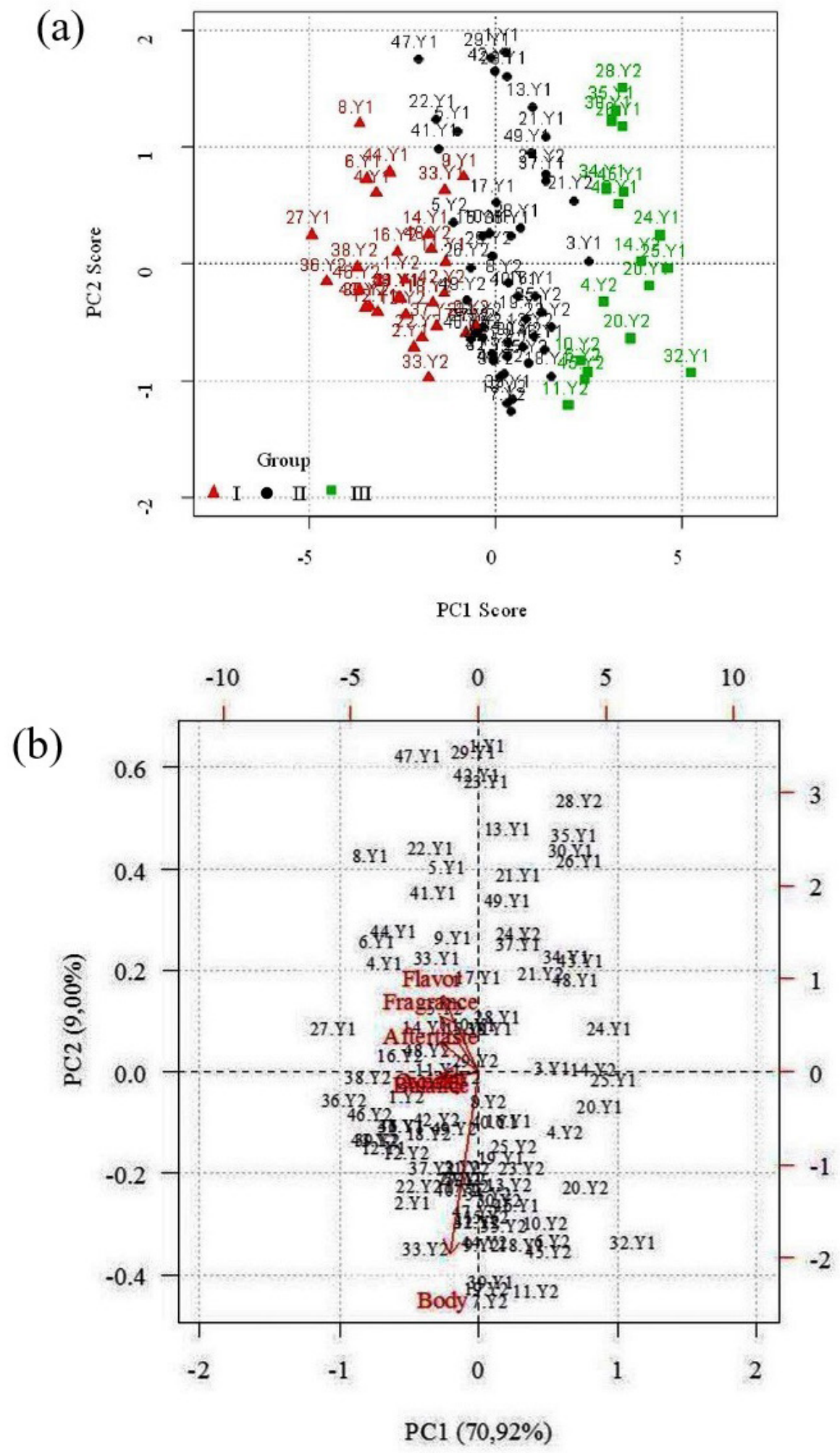

FIGURE 1 - PCA scores (a) and biplot of variables (b) for accesses of Coffea arabica L. of the GC, in two years of harvest, Y1 (2015) and Y2 (2016), in relation to sensory attributes. Group I: 84,0-86,3 points, Group II: 82,583,9 points, Group III: 80,3-82,4 points. 
TABLE 2 - Correlations between the evaluated parameters (sensorial attributes) and the first two main components, and the respective coefficients of each parameter with the main component.

\begin{tabular}{lcccc}
\hline \multirow{2}{*}{ Parameters } & \multicolumn{2}{c}{ PC1 $\mathbf{( 7 0 , 9 2 \% )}$} & \multicolumn{2}{c}{ PC2 (9,00\%) } \\
\cline { 2 - 5 } & Coefficients & Correlations* & Coefficients & Correlations* \\
\hline Fragrance & $-0,3961$ & $\mathbf{- 0 , 8 8 2 5}$ & 0,2681 & 0,2128 \\
Flavor & $-0,3820$ & $\mathbf{- 0 , 8 5 1 1}$ & 0,3673 & 0,2916 \\
Acidity & $-0,3789$ & $\mathbf{- 0 , 8 4 4 1}$ & $-0,0341$ & $-0,0271$ \\
Body & $-0,3023$ & $\mathbf{- 0 , 6 7 3 5}$ & $-0,8768$ & $\mathbf{- 0 , 6 9 6 0}$ \\
Aftertaste & $-0,3934$ & $\mathbf{- 0 , 8 7 6 5}$ & 0,1452 & 0,1152 \\
Balance & $-0,3786$ & $\mathbf{- 0 , 8 4 3 5}$ & $-0,0373$ & $-0,0296$ \\
Overall & $-0,4052$ & $\mathbf{- 0 , 9 0 2 8}$ & $-0,0284$ & $-0,0225$ \\
\hline
\end{tabular}

* Variables in bold and italics indicate groups of variables to be formed.

As mentioned, the group 2 allocated most of the accesses evaluated with a final score between 82.5 and 83.9 for the two years of harvest. Most of the accesses of this group, that is, 24 accesses presented variability for the expression of quality as a function of the year of harvest, being allocated in different groups; the other accesses presented less variability for beverage quality, between the two years of production remaining allocated in the same group. Evaluating the Kenyan germplasm bank, Kathurima et al. (2009) separated C. arabica genotypes into different clusters and subclusters according to beverage quality and found great diversity among genotypes for sensory attributes.

The group 1 consisted of accesses with a score higher than 84.0 points, highlighting the access 27 (Pacamara) in the first year of harvest with 86.3 points, and the access 36 (Híbrido de Timor UFV376-52) in the second year of harvest with 86.1 points. The Pacamara cultivar is a cross between the Pacas and Maragogipe cultivars, both of red fruits. The recombination of Maragogipe with Pacas, a cultivar of good production derived from Bourbon, has aroused great interest for possible future crosses (Lara et al., 2014). Assessing the quality of 20 cultivars of C. arabica, López-Garcia et al. (2016) found superiority for the Pacamara cultivar in terms of aroma, acidity, and body attributes and grain size, with a high percentage of grain on sieves 17 and 18 .

The accesses 36 (Híbrido de Timor UFV376-52) and 43 (BE5 Wush-Wush UFV 406-06) were the only accesses that in the two years of harvest were allocated in the groups with the highest sensorial scores that reached scores higher than 85 points, showing that the maximum expression of these genotypes for the production of coffee with excellent quality of beverage does not change depending on the year of harvest. In addition, these two accesses were also the most similar to each other for the first year of harvest and, according to Scholz et al. (2016), for genetic improvement purposes, it is important to classify genotypes with similar characteristics. The BE5 Wush-Wush access originates from Ethiopia, with the SH1 resistance factor (Rodrigues, Braghini and Guerreiro Filho, 2017) and has red fruits with early and uniform ripeness. The Híbrido de Timor genotype comes from the interspecific crossing of C. arabica and C. canephora and the descendants of this genotype are widely used in genetic improvement to promote resistance to various coffee diseases (Setotaw et al., 2010; Romero et al., 2014). In addition to being resistant to coffee tree diseases, several studies confirm that the Híbrido de Timor germplasm can be used as a source of genes to improve other characteristics of interest, such as coffee beverage. In this sense, Sobreira et al. (2016) evaluated the quality potential of the cross between BE5 Wush-Wush and Híbrido de Timor and observed final scores between 83.0 and 85.5 points. In addition, it is observed that all accesses of Híbrido de Timor in the second year of harvest, remained in group 1, corroborating with some authors that the Híbrido de Timor germplasm has high potential for producing higher quality coffee (Kathutima et al., 2009; Sobreira et al, 2015a; Sobreira et al., 2015b).

It is important to point out that the accesses of the Bourbon cultivar presented variability for the quality of the beverage, presenting in general, good quality with emphasis on the access 2 (Bourbon Amarelo) that stood out sensorially in both years of harvest, remaining in the group of accesses with better sensory scores. 


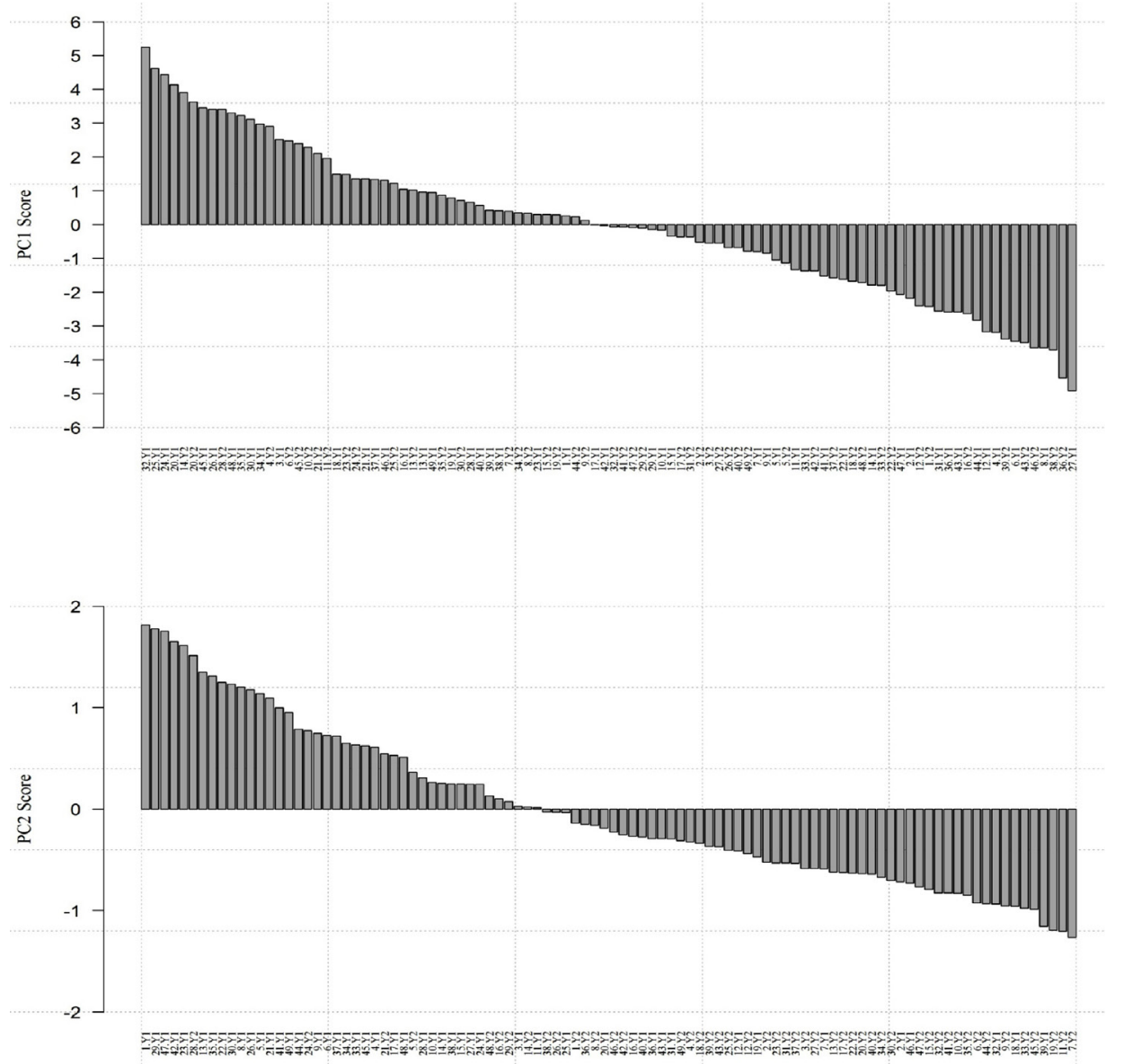

FIGURE 2 - PC1 (a) and PC2 (b) scores for data on 49 accesses of C. arabica in two years of evaluation, Y1 - Year 1 (2015) and Y2 - Year 2 (2016), according to the scores of sensory attributes.

The Bourbon cultivar is traditionally known as excellent for the production of specialty coffees, especially in conditions of high altitude and low temperature (Borém et al., 2016; Ferreira et al., 2012; Figueiredo et al, 2013); however, it is possible to observe that in the soil and climate conditions in which the GC is located, other materials have the same potential, or higher, such as accesses of Híbrido de Timor germplasm than the Bourbon cultivar to produce specialty coffees and can then be used in genetic improvement programs aimed at obtaining new cultivars with high potential for beverage quality.

\section{Characterization of sensory attributes of coffee: Content analysis}

We identified 139 terms used by tasters to describe the characteristics of the 49 accesses of Arabica coffee. However, only the terms cited in the two years of harvest were separated into categories and subcategories, as can be seen in Table 3. In the study by Donfrancesco et al. (2014),
59 terms were counted to characterize thirteen samples of Arabica coffee from Colombia, while Bhumiratana et al. (2011) raised only 13 terms associated with three varieties of coffee (Bourbon, Kebado and Kona) in three different regions, El Salvador, Ethiopia, and Hawaii. This observation demonstrates the variability existing in the access of the GC for the sensory attributes of the beverage.

From the associated terms, we transformed the subcategories into relative frequency for each access group formed by the PCA (Figure 4). In the Flavor category (Figure 4a), the caramel, chocolate, and fruity attributes were frequent in all access groups, but at different levels; in relation to the caramel attribute, it was found that the group I had the highest frequency $(48.17 \%)$ than the other groups. It is expected that the caramel attribute is present in all roasted coffee, since during the roasting process one of the most important steps is the caramelization of sugar, which occurs soon after the Maillard reaction and gives not only flavor and aroma to the coffee, but also characteristic coloration (Illy and Viani, 1995). 


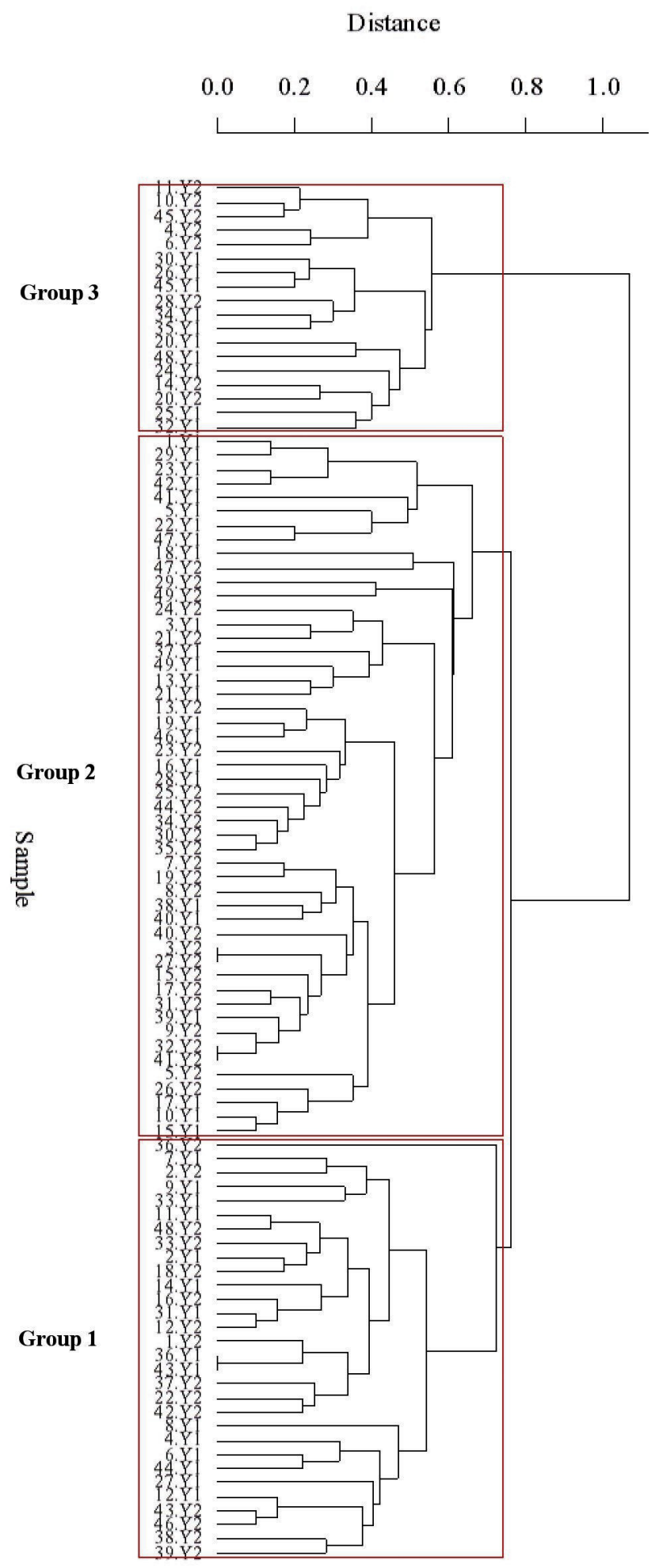

FIGURE 3 - HCA dendrogram for 49 accesses of Coffea arabica L. of the GC in function of two years of harvest, Y1 (2015) and Y2 (2016), in relation to the sensory scores. Group 1: 84.0 - 86.3 points. Group 2: 82.5 - 83.9 points. Group 3: 80.3 - 82.4 points. 
TABLE 3 - Terms identified by tasters in the Arabica coffee accesses of the GC for the two harvest years which were used in the content analysis.

\begin{tabular}{|c|c|c|}
\hline Category & Sub-category & Associated terms \\
\hline \multirow[t]{3}{*}{ Flavor } & Chocolate & Chocolate; Milk Chocolate; Light chocolate; Dark chocolate. \\
\hline & Fruity & $\begin{array}{l}\text { Fruity; Yellow fruits; Light fruity; Citrus fruits; Tangerine; Crys- } \\
\text { tallized fruits; Red fruits. }\end{array}$ \\
\hline & Caramel & $\begin{array}{l}\text { Caramel; Rapadura; Brown sugar; Honey; Molasses; Light } \\
\text { caramel; Garapa (sugarcane juice). }\end{array}$ \\
\hline \multirow[t]{3}{*}{ Fragrance/Aroma } & Fruity & Fruity; Yellow fruits. \\
\hline & Sweetened & Caramel; Sweet; Honey; Chocolate; Rapadura; Brown sugar. \\
\hline & Floral & Floral. \\
\hline \multirow[t]{2}{*}{ Sweetness } & High & Very sweet; Sweet; Good. \\
\hline & Average & Medium; Medium. \\
\hline \multirow[t]{3}{*}{ Acidity } & High & Present; Brilliant. \\
\hline & Sweet & Sweet; Sweet. \\
\hline & Medium/Pleasant & Medium; Pleasant; Citrus; Delicate; Medium. \\
\hline \multirow[t]{3}{*}{ Body } & Smooth & Creamy; Soft; Velvety; Round; Delicate. \\
\hline & Full-bodied & Full-bodied; Medium. \\
\hline & Strong & Dense. \\
\hline \multirow[t]{3}{*}{ Finishing } & Long & Long; Extended. \\
\hline & Refreshing & Refreshing. \\
\hline & Pleasant & Sweet; Pleasant; Enjoyable; Defined; Dry; Slightly dry. \\
\hline
\end{tabular}

Regarding the chocolate attribute, the tasters found a higher frequency in the accesses of group III (38.71\%), and a lower frequency of this attribute in groups I (15.77\%) and II (24.02\%). Bhumiratana et al. (2011) also found differences for the "chocolate/cocoa" attribute among coffee varieties grown in three distinct regions. Group I formed by the accesses with the highest sensory scores showed the highest frequency for the fruity attribute $(36.06 \%)$, therefore, it can be said that this attribute is important for the sensory classification of coffee.

For the Fragrance/Aroma category (Figure 4b), we observed that the most recurrent attribute between the groups is fruity, and the highest frequency was in the accesses of group III $(53.85 \%)$. The sweet nuances for fragrance and aroma were noticed in all the access groups, with the relative frequency being higher in group III $(46.15 \%)$. The floral attribute was present only in groups I (24.17\%) and II (12.38\%), with accesses with higher final scores, so it is possible to state that the floral aromas are more positive for the sensory quality of the coffee. The aromatic components are the main components of the sensory experience. The sweet aromas is the most intense and diluted and, consequently, easier to differentiate, especially between varieties and roasting points (Kreuml et al., 2013; Bhumiratana et al., 2011), in addition to the fact that odors with high intensities, such as sweetness, can mask and suppress other notes of less intense aroma (Grosch et al., 2001).

In the Sweetness category (Figure 4c), the highest frequency of the high sweetness attribute is observed for coffee accesses in groups I (98.13\%) and II $(93.12 \%)$ of better sensory quality. Nebesny and Budryn (2006) state that the sweetness has a beneficial impact on the overall harmony of coffee taste. This means that sweeter coffees are generally more balanced. Therefore, most of the accesses of the GC presented a very sweet and balanced taste. 

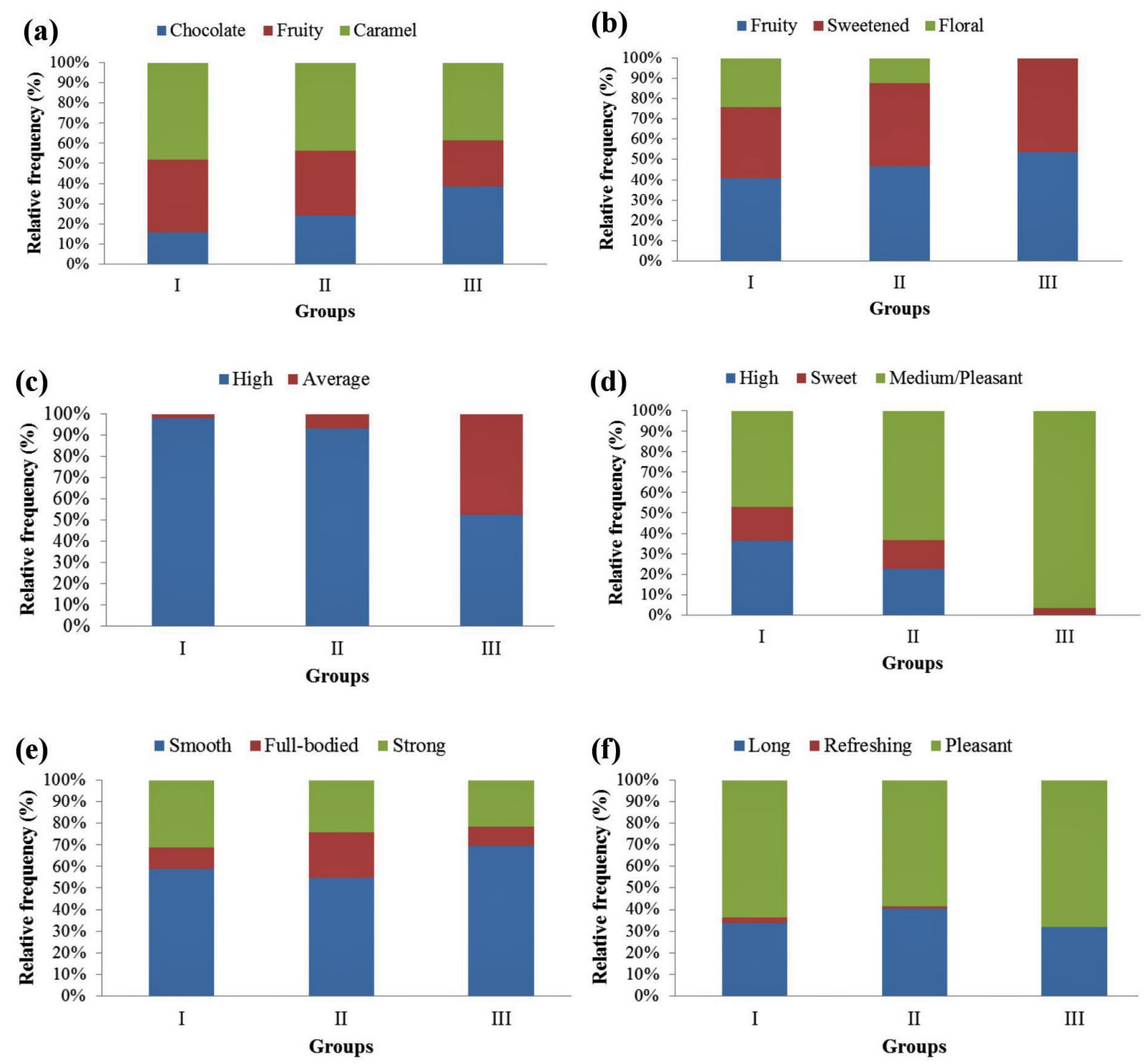

FIGURE 4 - Relative frequency of terms for the subcategories Flavor (a), Fragrance/aroma (b), Sweetness (c), Acidity (d), Body (e) and Finish (f) for each access group of Arabica coffee of the GC.

The acidity in the coffee can be desirable or not, depending on the acid present in the beverage. The desirable acidity contributes to the liveliness of the beverage, increasing the perception of sweetness and providing a flavor of dried fruits (Borém et al., 2016). According to Cheng et al. (2016), the acidity attribute varies drastically between varieties of the species C. arabica, while for the species $C$. canephora this attribute is described as low or non-existent. According to Figure $4 \mathrm{~d}$, it is possible to observe great variability for the category Acidity within the access groups. The mean acidity attribute was present in greater proportions in all groups of coffee accesses. More frequently is observed in group III (96.55\%).
Sweet acidity was also noticed in all groups but at lower frequencies in groups I (16.52\%), II $(13.94 \%)$ and III $(3.45 \%)$. On the other hand, high acidity was not noticed in group III coffee accesses, being more frequent in group I accesses $(36.31 \%)$, with better sensory quality. These observations corroborate with Sobreira et al. (2015) for genealogical groups of accesses of the GC of Minas Gerais. The authors also observed a higher frequency of "medium/bad" acidity in most of the groups evaluated.

In the Body category (Figure 4e), the soft, full-bodied and strong attributes were cited by tasters in all access groups, with the soft attribute having the highest frequency in group III $(69.57 \%)$ 
and the strong attribute in group I (31.28\%). The full-bodied attribute was more frequent in group II accesses (20.72\%). Finishing (Figure 4f) had a more homogeneous frequency for the attributes long finishing (I: $33.91 \%$, II: $40.52 \%$ and III: $31.82 \%$ ) and pleasant finishing (I: $63.51 \%$, II: $58.49 \%$ and III: $68.18 \%$ ). A small portion of accesses in group I $(2.58 \%)$ and II $(0.99 \%)$ presented refreshing finishing. Therefore, in general, the accesses of the GC are characterized by long and pleasant finishing. Evaluating the sensory attributes of cultivars of IAPAR together with Bourbon, Catuaí, Icatu, and Tupi, Scholz et al. (2013) highlighted groups of cultivars with more and less pronounced body depending on the cultivation environment and found no relation with finishing attributes (residual taste).

Thus, the study the sensory descriptions, with complementary analyses, in complex matrices such as coffee is an important step to extract the maximum information regarding the sensory profile and thus find possible singularities.

\section{CONCLUSIONS}

The GC represents an important collection of genotypes with high potential for beverage quality that can be used in improvement programs aimed at the production of cultivars for the specialty coffee market.

There is interference of the year of harvest in the final quality of some accesses, showing that in works involving the sensory quality of genotypes it is important the repeatability of the harvest in at least two years.

\section{ACKNOWLEDGMENTS}

The authors acknowledge the Agricultural Research Company of Minas Gerais (EPAMIG), the Federal University of Lavras (UFLA), the Coffee Innovation Agency (INOVACAFE), the Consórcio Pesquisa Café, FAPEMIG, CNPq, and CAPES.

\section{REFERENCES}

BARDIN, L. Análise de conteúdo. Lisboa: Edições 70, 1977

BHUMIRATANA, N. et al. Evolution of sensory aroma attributes from coffee beans tobrewed coffee. LWT Food Science and Technology, v.44, p.2185-2192, 2011. DOI: $10.1016 /$ j.lwt.2011.07.001
BORÉM, F.M. et al. The relationship between organic acids, sucrose and the quality ofspecialty coffees. African Journal of Agriculture Research, v.11, n.8, p.709-717, fev. 2016. DOI: 10.5897/AJAR2015.10569

CARVALHO, C.H.S. Cultivares de café: origem, características e recomendações.Brasília: Embrapa, 2008. 334p

CARVALHO, A.M. et al. Relationship between the sensory attributes and the quality of coffee in different environments. African Journal of Agricultural Research. v.11, p.3607-3614, 2016. DOI: 10.5897/ AJAR2016.11545

CHENG, B. et al. Influence of genotype and environment on coffee quality. Trends in Food Science \& Technology, v.57, part A, p.20-30. nov. 2016. DOI: 10.1016/j.tifs.2016.09.003

DONFRANCESCO, B. et al. Comparison of results from cupping and descriptive sensory analysis of Colombian brewed coffee. Journal of Sensory Studies, v.29, p.301-311, jun.2014. DOI:10.1111/joss.12104

FASSIO, L.O. et al. Sensory description of cultivars (Coffea arabica L.) resistant to rust and its correlation with caffeine, trigonelline, and chlorogenic acid compounds. Beverages, v.2, p.1-12, 2016. DOI: 10.3390/beverages 2010001

FERREIRA, A.D. et al. Análise sensorial de diferentes genótipos de cafeeiro Bourbon.Interciencia, v.37, p.390-394, 2012

FIGUEIREDO, L. P. et al. The Potential for HighQuality Bourbon Coffees From Different Environments. Journal of Agricultural Science, v. 5, n. 10, p. 87, 2013.DOI:10.5539/jas.v5n10p87

GIOMO, G.S; BORÉM, F.M. Cafés especiais do Brasil: opção pela qualidade. InformeAgropecuário, Belo Horizonte, v.32, n.261. 2011

GROSCH, W. Chemistry III: Volatile Compounds. In: CLARKE, R. J.;VITZTHUM, O. G. Coffee: Recent Developments. London: Blackwell Science, p.6889, 2001

ILLY, A.; VIANI, R. Espresso coffee: the chemistry of quality. London: Academic, 1995. 253p

KATHURIMA, C.W. et al. Evaluation of beverage quality and green bean physical characteristics of selected Arabica coffee genotypes in Kenya.African Journal of Food Science, v.3, n.11, p. 365-371, 2009 
KITZBERGER, C.S.G. et al. Profile of the diterpenes, lipid and protein content of different coffee cultivars of three consecutive crops. AIMS Agriculture and Food, v.1, p.254-264,2016. DOI: 10.3934/agrfood.2016.3.254

KREUML, M.T.L. et al. Changes in sensory quality characteristics of coffee during storage. Food Science \& Nutrition, v.1, n.4, p.267-272, 2013.DOI: 10.1002/ fsn 3.35

LARA, J.M.R.A. et al., Caracterização de formas botânicas diversas do Banco Ativo deGermoplasma de cafeeiros do Estado de Minas Gerais, Brasil. Bragantia, Campinas, v. 73, n. 4, p.383-389, 2014. http://dx.doi. org/10.1590/1678-4499.0208

LINGLE, T. R. The coffee cupper's handbook: a systematic guide to the sensory evaluation of coffee's flavor. Long Beach, CA: Specialty Coffee Association of America. 2011

LÓPEZ-GARCIA, F.J. et al. Produción y calidad em variedades de café (Coffea arabica L) em Veracruz, Mexico. Revista Fitotecnia Mexicana, vol. 39, n.3, p.297-304, 2016

NEBESNY, E.; BUDRYN, G. Evaluation of sensory attributes of brews from robusta coffee roasted under different conditions. European Food Research and Technology, v. 224 , n. 1, p. 159-165, 2006. DOI: 10.1007/s00217-006-0308-y

PEREIRA, M.C. et al. Multivariate analysis of sensory characteristics of coffee grains (Coffea arabica L.) in the region of upper Paranaíba. Acta Scientiarum. v.32, n.4, p.635-641, 2010. DOI: 10.4025/actasciagron. v32i4.4283

PEZZOPANE, J. R. M. et al. Agrometeorological parameters for prediction of the maturation period of Arabica coffee cultivars. International Journal of Biometeorology, v.56, p.843- 851, 2012. DOI: 10.1007/s00484-011-0486-6

R DEVELOPMENT CORE TEAM. R. a language and environment for statistical computing. Vienna: Foundation for Statistical Computing, 2017. Disponível em:<http://www.Rproject.org/> Acesso em: 26 abril 2017

RIBEIRO, D.E. et al. Interaction of genotype, environment, and processing in the chemical composition expression and sensorial quality of Arabica coffee. African Journal of Agricultural Research, v.11, n.27, p. 2412-2422, jul. 2016. DOI: 10.5897/AJAR2016.10832
RODRIGUES, L.M.R.; BRAGHINI, M.T.; GUERREIRO FILHO, O. SH1 leaf rust, and bacterial halo blight coffee resistances are genetically independent. Bragantia, v. 76, n. 2, p.209-213, 2017. DOI: $10.1590 / 1678-4499.171$

ROMERO, G. et al. Identification of a major QTL for adult plant resistance to coffee leaf rust (Hemileia vastatrix) in the natural Timor hybrid (Coffea arabicax Coffea canephora). Plant Breeding, v.133, p.121-129, 2014.DOI: 10.1111/pbr.12127

SCHOLZ, M. B. S. et al. Atributos sensoriais e características físico-químicas de bebida de cultivares de café do IAPAR. Coffee Science, Lavras, v. 8, n. 1, p. 6-16, 2013

SCHOLZ, M. B. S. et al. Chemical composition in wild ethiopian Arabica coffee accessions. Euphytica, v.209, p.429-438, fev. 2016. DOI: 10.1007/s10681016-1653-y

SETOTAW, T.A. et al. Breeding potential and genetic diversity of "Hibrido de Timor" coffee evaluated by molecular markers. Crop Breeding and applied biotechnology, v.10, p.298-304, 2010.DOI: 10.1590/ S1984-70332010000400003

SOBREIRA, F.M. et al. Sensory quality of arabica coffee (Coffea arabica) genealogic groups using the sensorgram and content analysis. Australian Journal of Crop Science, v.9, n.6, p.486-493. 2015 (a)

SOBREIRA, F.M. et al. Potential of Híbrido de Timor germplasm and its derived progenies for coffee quality improvement. Australian Journal of Crop Science, v.9, n.4, p.289-295, 2015 (b)

SOBREIRA, F.M. et al. Divergence among arabica coffee genotypes for sensory quality.Australian Journal of Crop Science, v.10, n.10, p.1442-1448, 2016. DOI:10.21475/ajcs.2016.10.10.p7430

TERESSA, A.D. et al. Genetic diversity of Arabica coffee (Coffea arabica L.) collection.European Journal of Applied Sciences and Technology, v.1, n.1, p.63-79, set. 2010

TESSEMA, A. et al. Genetic Diversity Analysis for Quality Attributes of Some Promising Coffea arabica Germplasm Collections in Southwestern Ethiopia. Journal Biological Sciences, v.11, n.3, p.236-244, 2011.DOI: 10.3923/jbs.2011.236.244

THURSTON, R. et al. Coffee: A comprehensive guide to the bean, the beverage, and the industry. Plymouth, UK: Rowman \& Littlefield. 2013 